\title{
List of Illustrations and Photographic Credits
}

Every effort has been made to contact all copyright holders. The publishers will be pleased to amend in future editions any errors or omissions brought to their attention.

\section{LIST OF PLATES}

I. Ships in dry dock, Singapore, c. I896. Balean/TopFoto.

2. Sikh policeman, Nanjing Road, Shanghai, I9ros. Gamma-Keystone/Getty Images.

3. The 'Maniktola garden', Calcutta. Wikimedia Commons.

4. Khudiram Bose, 1907. Historic Collection/Alamy.

5. Aurobindo Ghose, 1908. Historic Collection/Alamy.

6. Gurdit Singh on the Komagata Maru, I9I4. 9I4 Collection/Alamy.

7. Women tobacco workers, Sumatra, c. I9I4, photograph originally published in the contemporary journal Deli Planters Vereeniging.

8. Poster for Colonial Exhibition, Semarang, I9I4. Lithograph by Albert Hahn Snr. Lithograph on paper mounted on linen, I08.5 x $82.5 \mathrm{~cm}$. Collection of National Gallery Singapore, image courtesy of National Heritage Board.

9. Funeral procession for Mewa Singh, Vancouver, I915. Simon Fraser University Library Special Collections, Kohaly Collection.

Io. Maulana Barakatullah and Raja Mahendra Pratap, Mesopotamia, 1915. () Stiftung Bibliotheca Afghanica, Bubendorf.

II. Execution of rebel sepoys, Singapore, I9I5. Imperial War Museum, London. (C) IWM (Q 82506).

I2. Henk Sneevliet, Betsy Brouwer, their sons and servants, Semarang, c. I919. International Institute of Social History, Amsterdam (BG T2/732). 
I3. Crowds during the Congress of the Peoples of the East, Baku, I920. RIA Novosti/Sputnik/TopFoto.

I4. Delegates at the 2nd World Congress of the Communist International, Petrograd, I920. SCRSS/TopFoto.

I5. Nguyen Ai Quoc with delegates, $5^{\text {th }}$ World Congress of the Comintern, Moscow, I924. Sputnik/Alamy.

I6. Sarekat Islam meeting, Kaliwoengoe, Java, I92 I. Nationaal Museum van Wereldculturen, Leiden (Coll. No. TM-60009089).

I7. Painted textile depicting the arrest, trial and execution of a group of Javanese, Central Java, c. I920-30s. Nationaal Museum van Wereldculturen, Leiden (Coll. No. TM-59IO-I).

I8. The Prince of Wales and Chinese community leaders, Singapore, I922. Courtesy of National Archives of Singapore, Peng Song Toh Collection.

I9. Anti-Japanese patriotic demonstration, Shanghai, I922. Bettmann/Corbis/Getty Images.

20. Asian Delegates at the Comintern Congress, Moscow, I922. International Institute of Social History, Amsterdam (BG A60/622).

2I. 'The anarchist group', Singapore, c. I924. Archives Nationales d'Outre Mer, Aix-en-Provence (File/Fond, Indochine, GG, 65533).

22. Seating plan for dinner at the Hotel Victoria, Canton, I924. Archives Nationales d'Outre Mer, Aix-en-Provence (File/Fond, Indochine, $G G, 65533$ ).

23. Vietnamese students and Whampoa cadets at the tomb of Pham Hong Thai, c. 1925. Archives Nationales d'Outre Mer, Aix-enProvence (File/Fond, Indochine, GG, 65533).

24. Shamian island in the wake of Pham Hong Thai's bomb, Canton, I924. Archives Nationales d'Outre Mer, Aix-en-Provence (Filel Fond, Indochine, GG, 65533).

25. The bicycle party, Canton, c. late 1924. Archives Nationales d'Outre Mer, Aix-en-Provence (File/Fond, HCI, SPCE, 365).

26. The Shaji incident, 23 June 1925: before. Historical Photographs of China, University of Bristol (www.hpcbristol.net).

27. The Shaji incident, 23 June I925: after. Historical Photographs of China, University of Bristol (www.hpcbristol.net).

28. Students salute the cortege of Sun Yat-sen, Beijing, I925. Photograph by Sidney D. Gamble. Duke University Libraries, Sidney Gamble Collection. 
29. Borodin, Zhang Tailei and Wang Jingwei, Canton, 1926. Photograph by Fu Bingchang. Image courtesy of C. H. Foo, Y. W. Foo and Historical Photographs of China, University of Bristol (www. hpcbristol.net).

30. The British Bund, Hankou, 1927. PA Images.

3I. Xiang Jingyu, 1928. Source unknown.

32. Mas Marco Kartodikromo and his wife in Boven Digoel, 1932. Leiden University Libraries, Royal Netherlands Institute of Southeast Asian and Caribbean Studies (KITLV 4452).

33. Tan Malaka, I932. Harry A. Poeze, Tan Malaka: Strijder voor Indonesië's Vrijheid: Levens-loop van I897 tot I945, 's-Gravenhage, Nijhoff, 1976, p. 426.

\section{ILLUSTRATIONS IN THE TEXT}

Frontispiece: Nguyen Ai Quoc in Paris. Archives nationales d'outremer, Aix-en-Provence (File/Fond, HCI, SPCE, 364).

p. 2 Pham Hong Thai, 1924. Archives nationales d'outre-mer, Aix-enProvence (File/Fond, Indochine, GG, 65533).

p. 22 Phan Boi Chau, Prince Cuong De and Phan Chu Trinh in Japan, 1906. Archives nationales d'outre-mer, Aix-en-Provence (Filel Fond, INDO, RSTNF, 666I).

p. 54 An Act of Banishment: Page from a Criminal Registry, Singapore, I9I4. The National Archives, Kew (TNA, CO 273/420).

p. 96 Madame Cama in Stuttgart, 1907. International Institute of Social History, Amsterdam (BG B9/835).

p. I34 The viceroy's State Entry into Delhi, 23 December 19I2, illustration from La Tribuna Illustrata, January I9I3. Look and Learn/ Bridgeman Images.

p. I70 Bhagwan Singh with a samurai sword, Yokohama, I9I4. Courtesy of Surinder Pal Singh and the South Asian American Digital Archive.

p. 206 Ibrahim gelar Datuk Tan Malaka, c. I922. Leiden University Libraries, Royal Netherlands Institute of Southeast Asian and Caribbean Studies (KITLV I7800).

p. 240 At the gateway to India: Raja Mahendra Pratap in Afghanistan, I9I5. (C) Stiftung Bibliotheca Afghanica, Bubendorf. 
p. 278 M. N. Roy in Mexico. Photograph reproduced in Sibnarayan Ray, Selected Works of M. N. Roy: I9I7-I922, OUP, 1987.

p. 3 I6 Mas Marco Kartodikromo and his wife, abroad, c. I920. Leiden University Libraries, Royal Netherlands Institute of Southeast Asian and Caribbean Studies (KITLV 445I).

p. 362 Calling card of Nguyen Ai Quoc. Archives nationales d'outremer, Aix-en-Provence (File/Fond, HCI, SPCE, 365).

p. 4I6 The Great World, Shanghai, photograph by Jack Birns, I940s. The LIFE Picture Collection/Getty Images.

p. 468 Front cover of pamphlet by Tan Malaka, Indonezija i ee mesto na probuždajuščemsja vostoke (Indonesia and Its Place in the Awakening East), 1924. International Institute of Social History, Amsterdam (1992/3905).

p. 506 Wong Sang, the 'bobbed-haired woman'. Archives nationales d'outre-mer, Aix-en-Provence (File/Fond, Indochine, GG, 65533).

p. 554 Chiang Kai-shek enters Shanghai, April 1927. SZ Photo/Scherl/ Mary Evans.

p. 6I6 The abandoned typewriter of Nguyen Ai Quoc, Kowloon, I93I. Archives nationales d'outre-mer, Aix-en-Provence (File/Fond, HCI, SPCE, 365). 